\title{
Differences in fitness-associated traits between hatchery and wild chum salmon despite long-term immigration by strays
}

\author{
Casey J. McConnell ${ }^{1, *}$, Peter A. H. Westley ${ }^{2}$, Megan V. McPhee ${ }^{1}$ \\ ${ }^{1}$ College of Fisheries and Ocean Sciences, University of Alaska Fairbanks, 17101 Point Lena Loop Rd, Juneau, AK 99801, USA \\ ${ }^{2}$ College of Fisheries and Ocean Sciences, University of Alaska Fairbanks, 905 N. Koyukuk Drive, Fairbanks, AK 99775, USA
}

\begin{abstract}
To assess the potential for introgression and competition between hatchery-produced $\left(\mathrm{H}_{\mathrm{p}}\right)$ and natural-origin $\left(\mathrm{N}_{\mathrm{o}}\right)$ chum salmon Oncorhynchus keta, we quantified a suite of fitnessrelated morphological and life-history traits on the spawning grounds of a small creek in Southeast Alaska that has high rates of immigration from nearby hatchery programs. Using thermally marked otoliths to distinguish between $\mathrm{H}_{\mathrm{p}}$ and $\mathrm{N}_{\mathrm{o}}$ fish, we estimated that $51.4 \%$ of individuals examined in 2015 were $\mathrm{H}_{\mathrm{p}}$ strays. Compared with their $\mathrm{N}_{\mathrm{o}}$ counterparts, $\mathrm{H}_{\mathrm{p}}$ males and females entered the creek significantly later, were younger at maturity, smaller in body length, and smaller for a given age. On average, $\mathrm{H}_{\mathrm{p}}$ females lived $2 \mathrm{~d}$ less on the spawning grounds than $\mathrm{N}_{\mathrm{o}}$ females and also had higher rates of egg retention ( $47 \mathrm{vs.} 19 \%$ observed in $\mathrm{N}_{\mathrm{o}}$ females). The observed phenotypic differences between the local $\mathrm{N}_{\mathrm{o}}$ and $\mathrm{H}_{\mathrm{p}}$ individuals suggest barriers to introgression through combinations of selection against strays or spatio-temporal segregation on the spawning grounds, though the phenotypic baseline of the $\mathrm{N}_{\mathrm{o}}$ population prior to potential hatchery influence is not known, nor is the extent to which environmental plasticity may be influencing trait expression. Although rates of interbreeding may be sufficiently low to currently maintain phenotypic differences between $\mathrm{N}_{\mathrm{o}}$ and $\mathrm{H}_{\mathrm{p}}$ strays, at least some spawning did occur by the majority of $H_{p}$ individuals. Ultimately, it remains unclear how long the presumably adaptive phenotype of the $\mathrm{N}_{\mathrm{o}}$ population may persist given the consistently large numbers of strays appearing annually on the spawning grounds.
\end{abstract}

KEY WORDS: Homing · Dispersal · Enhancement · Hatchery · Competition · Introgression · Local adaptation $\cdot$ Oncorhynchus keta

\section{INTRODUCTION}

Atlantic and Pacific salmon (Salmo and Oncorhynchus spp., respectively) are well known for natal site fidelity for reproduction (Foerster 1937, Scheer 1939, Hasler \& Wisby 1951). This homing behavior facilitates reproductive isolation (Quinn 1993, Hendry et al. 2000, Jonsson et al. 2003, Schtickzelle \& Quinn 2007), which, combined with natural selection, promotes the evolution of locally adapted populations (Taylor 1991, Hendry 2004, Fraser et al. 2011, Peterson et al. 2014). Individual salmon that return to spawn in non-natal freshwaters, termed 'strays', are

${ }^{*}$ Corresponding author: casey.fishes@gmail.com thought to reflect hedges against environmental disturbance (Leider 1989), provide a mechanism for colonization (Pess et al. 2012, Nielsen et al. 2013), and increase genetic diversity via gene flow (Consuegra et al. 2005, McPhee et al. 2014).

Although straying is a fundamental aspect of salmon biology, the ecological and genetic impacts of strays produced from aquaculture on naturally occurring populations continue to be of concern in North America and Europe (Jonsson et al. 2003, McGinnity et al. 2003, Rand et al. 2012). Chief among these concerns are spread of disease, domestication, reduction in genetic diversity, and the loss of local adaptation of

() The authors 2018. Open Access under Creative Commons by Attribution Licence. Use, distribution and reproduction are unrestricted. Authors and original publication must be credited. 
native stocks through hybridization and introgression of maladaptive, non-native alleles (Waples 1991, Heggberget et al. 1993, Naish et al. 2007). It is well known that introgression of non-native alleles and hybridization between genetically distinct populations can result in the loss of local adaptation and reductions in fitness resulting from outbreeding depression (Gharrett \& Smoker 1991, McClelland et al. 2005, Muhlfeld et al. 2009). This sequence of events is exacerbated by hybridization with distantly related populations or populations that have diverged through natural or artificial selection pressures (Gharrett et al. 1999, McClelland \& Naish 2007, Bolstad et al. 2017).

Selection pressures experienced by salmon born in nature differ from those reared in captivity. For example, the hatchery environment relaxes selection pressures from predators and can alter competitive interactions and selective pressures on body size and prominent secondary sexual characteristics (Fleming \& Gross 1989, Hendry et al. 2004, Knudsen et al. 2006). Adaptation to the artificial environment of hatcheries increases reproductive success within the hatchery system, but results in lowered reproductive success of hatchery salmon in the wild (Fleming \& Gross 1994, Fleming et al. 1996, Reisenbichler \& Rubin 1999, Ford 2002, McGinnity et al. 2003, Araki et al. 2007, Frankham 2008). Moreover, genetic changes driven by spawning and rearing in the hatchery environment can occur over contemporary timeframes (Fleming \& Einum 1997), even after a single generation in captivity (Christie et al. 2012, 2016).

Currently, over 5 billion juvenile Pacific salmon are released annually in the North Pacific basin (North Pacific Anadromous Fish Commission 2016), and even small rates of straying can result in hatcheryproduced individuals overwhelming numerically small naturally occurring populations (Waples 1999, Bett et al. 2017). For example, 650 million juvenile chum salmon Oncorhynchus keta are released each year from Alaska's hatcheries (North Pacific Anadromous Fish Commission 2016). Chum salmon returns to Southeast Alaska since 1980 have ranged from 1.8 to 10 million natural adults and 0.1 to 14 million hatchery adults (Ruggerone et al. 2010). Recent studies in Alaska report that hatchery chum salmon can comprise from 0 to up to $78 \%$ of the returning adults in some natural systems (Piston \& Heinl 2012). This disparity in recipient stray rates is largely reflective of the distance streams were from hatchery-release locations, the size of wild populations, and likely physical aspects of the recipient streams that makes them attractive or unattractive to strays (Brenner et al. 2012, Bett et al. 2017).
While our understanding of the geographic extent and rates of hatchery strays in natural systems is expanding, it is not known what ecological mechanisms are prohibiting or promoting interactions in the wild. To date, it is not known whether Alaskan hatchery-produced $\left(\mathrm{H}_{\mathrm{p}}\right)$ and natural-origin $\left(\mathrm{N}_{\mathrm{o}}\right)$ adult chum salmon differ in phenotypic traits such as run timing, body size, or body shape, which may either facilitate or inhibit genetic interactions. Understanding the intricacies of factors determining relative reproductive success may help identify ecological mechanisms regulating genetic interactions.

In this paper, we compared a suite of fitnessrelated phenotypic traits between the presumed local $\mathrm{N}_{\mathrm{o}}$ adult chum salmon and $\mathrm{H}_{\mathrm{p}}$ strays spawning in a small representative watershed, Sawmill Creek, in Southeast Alaska. Prior straying studies estimated recipient stray rates in Sawmill Creek as $8 \%$ in 1995, $78 \%$ in 1996 and 2009 and $47 \%$ in 2010 (Josephson 2010 , Piston \& Heinl 2012). We note that only $61 \%$ of hatchery returns in 1995 (brood year 1991) were thermal marked, and that the $8 \%$ hatchery component is not expanded to account for the possibility of unmarked hatchery salmon (Josephson 2010). Given the close proximity to release locations, small size of the naturally occurring population (Piston \& Heinl 2014), high recipient stray rates, and short stream length, Sawmill Creek is a prime location for exploring interactions between hatchery and natural salmon on the spawning grounds. By sampling chum salmon throughout the spawning season, we examined the potential for ecological and reproductive interactions between hatchery and natural salmon while controlling for potentially confounding influences of migration distance and observer bias. Specifically, our objectives were to quantify differences between $\mathrm{H}_{\mathrm{p}}$ and $\mathrm{N}_{\mathrm{o}}$ chum salmon in the following traits: (1) freshwater entrance timing, (2) body size and shape, (3) age at maturity, (4) instream lifespan, and (5) egg retention rates. These traits were chosen based on their established genetic basis in salmonids (Carlson \& Seamons 2008), widespread divergence among locally adapted populations (reviewed in Quinn 2005), and known effects on fitness (Taylor 1991, Fleming \& Gross 1994).

\section{MATERIALS AND METHODS}

\section{Site description}

Sawmill Creek $\left(58.715^{\circ} \mathrm{N}, 134.944^{\circ} \mathrm{W}\right)$ is located approximately $40 \mathrm{~km}$ north of Juneau, Alaska 


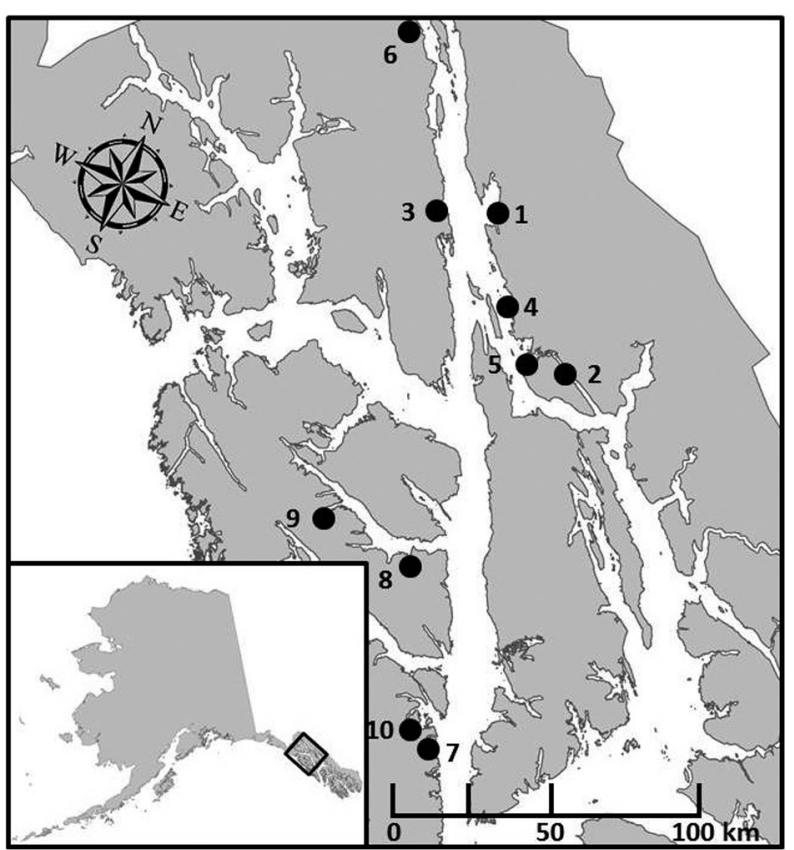

Fig. 1. Northern southeast Alaska depicting Sawmill Creek (1) and DIPAC hatchery (2); remote release locations of Boat Harbor (3) and Amalga Harbor (4); and source locations for Douglas Island Pink and Chum (DIPAC) broodstock as defined in Stopha (2014) as Sawmill Creek (1), Fish Creek (5), and Klehini River (6), as well as Salmon Creek and Kowee Creek (not shown; each within $3 \mathrm{~km}$ of DIPAC). Hidden Falls Hatchery (7) stocks were developed from Kadashan River (8), Seal Bay Cove (9), and Clear River (10)

(Fig. 1). It is a short stream $(7 \mathrm{~km})$, with approximately $500 \mathrm{~m}$ of available spawning habitat accessible to anadromous fish due to an impassable (ca. $15 \mathrm{~m}$ high) waterfall. The average width of Sawmill Creek is approximately $15 \mathrm{~m}$, and estimated discharge ranges from 0.5 to $1.12 \mathrm{~m}^{3} \mathrm{~s}^{-1}$ during summer base flow (i.e. it is not strongly influenced by heavy rains or significant snow melt). The number of chum salmon entering Sawmill Creek is highly variable among years, with aerial or foot survey estimates between 100 and 4500 made during previous surveys (Piston \& Heinl 2014).

\section{Hatchery description}

The history of the broodstock developed for release closest to Sawmill Creek has included chum salmon from Sawmill Creek and 4 other stocks from northern Southeast Alaska, as well as supplemental broodstock from Hidden Falls Hatchery comprised of 3 stocks from southern Southeast Alaska (Stopha 2014, Fig. 1). The broodstock at Douglas Island Pink and
Chum (DIPAC) hatchery is a segregated stock, as adults that return to the hatchery are used for broodstock, and it is unlikely that few if any $\mathrm{N}_{\mathrm{o}}$ salmon stray into the hatchery raceway, though these rates are unknown.

Upon emergence in the hatchery, juvenile chum salmon are moved to saltwater pens and grown for several months before being released on-site near the hatchery or transported, grown, and released at remote locations to create site-specific harvest opportunities for commercial fisheries. Two remote release locations are located within $30 \mathrm{~km}$ of Sawmill Creek: Amalga Harbor $\left(58.49^{\circ} \mathrm{N}, 134.79^{\circ} \mathrm{W}\right)$ and Boat Harbor $\left(58.63^{\circ} \mathrm{N}, 135.16^{\circ} \mathrm{W}\right)$ (Fig. 1). Combined releases of chum salmon fry at these 2 locations averaged 61 million individuals annually from 2010 to 2015 (White 2011, Vercessi 2012, 2013, 2014, 2015, Stopha 2016).

\section{Data collection}

Intensive sampling of Sawmill Creek took place throughout the 2015 spawning season. Fish were sampled between 7 July (the day after chum salmon were first observed entering the creek) and 21 August (no live chum salmon remained), though the creek was visited several times just prior to the run and just after to confirm exact start and end dates. Most of the 26 visits over the $46 \mathrm{~d}$ season consisted of an exhaustive carcass survey throughout the entire area available to spawning fish and into the forest approximately $10 \mathrm{~m}$ on each side of the creek to account for removal by bears (Ursus spp.). Every carcass was measured for length $\left(\mathrm{mm}_{\text {; }}\right.$ mid-eye to end of hypural plate, hereafter referred to as MEHL). Carcasses of un-scavenged females were dissected and remaining eggs were counted to estimate egg retention. Sagittal otoliths were removed from all carcasses found in Sawmill Creek and stored until they could be read to detect the absence or presence of a thermal mark indicating natural or hatchery origin (Volk et al. 1999). Live chum salmon were enumerated throughout the entire creek from the barrier falls down to the high tide line (except when poor water clarity obscured identification of fish in deep pools; see Table 1).

A mark-recapture experiment was conducted to estimate instream lifespan, which also allowed an estimate of the escapement population size by using a Chapman estimator (Seber 1982). To obtain accurate estimates of entrance date and lifespan, only chum salmon that had recently entered Sawmill 
Creek (based on vibrant coloration and lack of signs of spawning activity) were targeted for tagging using dipnets and angling gear. Captured fish were anesthetized with Aqui-S 20E® (35 ppm), measured for MEHL, body depth (vertically from insertion of dorsal fin), and snout length (tip of snout to mid-eye). Fish were then marked with individually labeled 1 inch Peterson disc tags and their sex was recorded before recovery and release.

While the age of $\mathrm{H}_{\mathrm{p}}$ salmon was readily determined by specific thermal marks (linked to brood year), the age of $\mathrm{N}_{\mathrm{o}}$ chum salmon were estimated from otoliths following the interpretation of annuli described in Bilton \& Jenkinson (1968). If consensus could not be reached by multiple readers, no age was assigned to that individual $(\mathrm{n}=17)$. Verification of presence/ absence and thermal code identifications were made by professional readers at Alaska Department of Fish and Game Mark, Tag, and Age Lab in Juneau, Alaska following standardized quality control protocol procedures described by Fernandez \& Moffitt (2016).

\section{Statistical analysis}

Entrance timing onto the spawning grounds. $H_{p}$ and $\mathrm{N}_{\mathrm{o}}$ groups were assessed using non-parametric Kruskal-Wallis tests to determine whether groups (separated by sex) significantly differed with regards to entrance timing distributions.

Body length, body depth, and snout length. ANCOVA was used to compare morphological traits between $\mathrm{H}_{\mathrm{p}}$ and $\mathrm{N}_{\mathrm{o}}$ chum salmon within Sawmill Creek while controlling for seasonal trends following the form:

$$
y_{i k}=\mu_{k}+\beta_{k} x+\varepsilon_{i k}
$$

where $y$ is the trait value for fish $i$ of origin $k$ (body length, depth, or snout length of natural or hatcheryproduced), $\mu$ is the mean response for $\mathrm{N}_{\mathrm{o}}$ or $\mathrm{H}_{\mathrm{p}}$ (intercept), $\beta$ is the effect of date $(x)$ on the response (covariate), which may differ between hatchery and wild fish, and $\varepsilon$ is the residual error term. Regression slopes were estimated for models containing $\mathrm{N}_{\mathrm{o}}$ and $\mathrm{H}_{\mathrm{p}}$ salmon by including an interaction term in the model $\left(\mathrm{B}_{k}\right)$, which was then removed if found to be insignificant ( $p>0.05)$, in which case we used a simplified model with common slopes between groups:

$$
y_{i k}=\mu_{k}+\beta x+\varepsilon_{i k}
$$

We used a temporal covariate because larger, older individuals typically enter streams first (Clark \&
Weller 1986, Morbey 2000). If a seasonal trend was not identified as significant it was removed from the model, resulting in an ANOVA. Because secondary sexual characters such as body depth and jaw length shrink after spawning and are thus not necessarily representative of an individual's spawning morphology (Quinn \& Blair 1992, Hendry \& Berg 1999), untagged carcasses recovered after senescence were measured only for MEHL. To control for the effect of body size on trait values, body depth and snout length were standardized to a common body length for each sex $($ males $=537 \mathrm{~mm}$, females $=510 \mathrm{~mm}$ ) following Hendry \& Quinn (1997) prior to comparison by ANCOVA.

Age at maturity. Kruskal-Wallis tests were performed to account for non-parametric age-atmaturity distributions and to compare ages of $\mathrm{H}_{\mathrm{p}}$ and $\mathrm{N}_{\mathrm{o}}$ chum salmon by sex. Age- 4 and -5 fish comprised $94 \%$ of the aged returns to Sawmill Creek (see Table 3). Although age-3 and -6 chum salmon were recovered, sample sizes were not large enough ( $\mathrm{n}=13$ and 6 , respectively) to conduct statistical comparisons.

Length at age. Body length (i.e. MEHL) measurements of age- 4 and $-5 \mathrm{H}_{\mathrm{p}}$ and $\mathrm{N}_{\mathrm{o}}$ chum salmon were analyzed using ANCOVA tests while controlling for the temporal covariate of the day of year the carcass was recovered. If the temporal covariate was not significant it was removed and ANOVA tests were used for the comparisons.

Instream lifespan. Instream lifespan was calculated as the number of days between entrance date and observed death date of recovered tagged salmon that died of natural causes. ANCOVA was used to compare instream ifespan of $\mathrm{H}_{\mathrm{p}}$ and $\mathrm{N}_{\mathrm{o}}$ fish of both sexes while controlling for seasonal trends by including entry date as a covariate (similar to ANCOVA tests for length previously described). If entry date was not significant it was removed, and ANOVA tests were used to determine differences in lifespan between $\mathrm{H}_{\mathrm{p}}$ and $\mathrm{N}_{\mathrm{o}}$ groups.

Egg retention. Egg retention was expressed as the percentage of eggs retained relative to total estimated fecundity as predicted from the fish's MEHL. To develop a length-fecundity relationship, we sampled 10 fully mature females from the fish ladder at the DIPAC hatchery and 25 ripe $\mathrm{H}_{\mathrm{p}}$ females from Salmon Creek directly adjacent to the hatchery. Volumetric displacement was used to determine the pooled average volume of an individual egg $(0.25 \pm 0.04 \mathrm{ml})$ and remaining eggs were then displaced to determine total gonad volume. The gonad volume-to-length relationship was estimated with a general linear model 
$\left(\mathrm{r}^{2}=0.38, \mathrm{p}<0.001\right)$ and expected fecundities (in number of eggs) were calculated by using model coefficients and the observed length to calculated expected egg volume, then dividing the expected volume by the pooled average egg volume to get expected fecundity as number of eggs. Egg retention percentages were then calculated by dividing number of counted eggs that remained in unscavenged body cavities by the expected fecundity (similar to Quinn et al. 2007a). As observed elsewhere (Beacham \& Murray 1993, Fleming \& Gross 1994), the relationship between body length and fecundity was significant but highly variable, likely reflecting tradeoffs between egg size and egg number.

A generalized linear model (GLM) was used to compare the estimated percentage of eggs retained in the body cavity of dead $\mathrm{H}_{\mathrm{p}}$ and $\mathrm{N}_{\mathrm{o}}$ females while controlling for the effect of death date. A binomial distribution and logit link function were specified and interaction terms were tested. If interaction terms were insignificant they were removed from the model.

All statistical tests and data manipulations were conducted using R version 3.2.2 (2015) and statistical significance was based on $\alpha=0.05$.

\section{RESULTS}

A total of 184 chum salmon entering the spawning grounds of Sawmill Creek in 2015 were tagged and released; 121 of those tagged individuals were recovered: 18 were killed by bears and the remaining 103 died either naturally $(\mathrm{n}=99)$ or of an undetermined cause $(\mathrm{n}=4)$. The remaining 63 tagged fish were either washed out of the stream after senescence or carried off by predators and not recovered. Tagging effort bracketed the entire run and sampling was most intensive during the peak of the run; thus, tagged fish were likely representative of the 2015 spawning population as a whole. Additionally, all data used for hatchery/wild comparisons came from confirmed-origin carcasses, of which all were sampled, reducing potential subsampling bias (Table 1).

Otoliths from 560 of 561 chum salmon were readable for the presence/absence of a thermal mark, of which $51.4 \%$ were identified as $\mathrm{H}_{\mathrm{p}}$ origin. Of knownorigin fish, $23 \mathrm{~N}_{\mathrm{o}}$ and $35 \mathrm{H}_{\mathrm{p}}$ chum salmon were killed by bears (ca. $13 \%$ of all chum salmon deaths), 2 fish died of unknown causes, 1 died from stranding on an exposed gravel bar, and the remainder were found to be senescent. Using a Chapman estimator, we conservatively estimate $854 \pm 40$ spawners in Sawmill
Creek in 2015. According to this estimate, and assuming a closed population (i.e. no tagged fish left Sawmill Creek during the tag recovery period), we sampled approximately 62 to $68 \%$ of the spawning population.

\section{Entrance timing}

$\mathrm{N}_{\mathrm{o}}$ chum salmon entered the creek earlier than $\mathrm{H}_{\mathrm{p}}$ strays (Fig. 2). Median entry for $\mathrm{N}_{\mathrm{o}}$ males was 17 July, which was significantly earlier than that of $\mathrm{H}_{\mathrm{p}}$ males, whose median entry day was 27 July (Kruskal-Wallis, $\left.\chi^{2}=10.12, \mathrm{df}=1, \mathrm{p}=0.001\right)$. Entrance timing also differed in females (Kruskal-Wallis, $\chi^{2}=10.65, \mathrm{df}=1$, $\mathrm{p}=0.001$ ), with a median date of 24 July for $\mathrm{N}_{\mathrm{o}}$

Table 1. Run timing, tagging effort, and carcass recoveries during the 2015 chum salmon spawning season. Live count: number of live chum salmon observed within Sawmill Creek on that date; tagged/recovered: number of fish tagged on that date and the number of deployed tags from that sample day that were eventually recovered later in the season; carcasses recovered: number of both tagged and untagged carcasses (for which origin was positively identified) sampled on date of visit. (-) dates Sawmill Creek was visited but counts or tagging did not occur; non-sequential dates indicate which days Sawmill Creek was not visited

\begin{tabular}{|c|c|c|c|}
\hline $\begin{array}{l}\text { Date } \\
\text { (mm/dd/yyyy) }\end{array}$ & $\begin{array}{l}\text { Live } \\
\text { count }\end{array}$ & $\begin{array}{l}\text { Tagged/ } \\
\text { recovered }\end{array}$ & $\begin{array}{l}\text { Carcasses } \\
\text { recovered }\end{array}$ \\
\hline 07/06/2015 & 10 & - & 0 \\
\hline 07/07/2015 & 20 & - & 0 \\
\hline 07/08/2015 & - & $3 / 0$ & 0 \\
\hline 07/10/2015 & - & $2 / 0$ & 0 \\
\hline $07 / 12 / 2015$ & - & $9 / 7$ & 1 \\
\hline $07 / 14 / 2015$ & 72 & $10 / 6$ & 0 \\
\hline $07 / 15 / 2015$ & 108 & $18 / 13$ & 4 \\
\hline $07 / 16 / 2015$ & 103 & $17 / 16$ & 0 \\
\hline $07 / 19 / 2015$ & 134 & $12 / 5$ & 11 \\
\hline $07 / 20 / 2015$ & 137 & $2 / 2$ & 16 \\
\hline $07 / 22 / 2015$ & 132 & $5 / 5$ & 48 \\
\hline 07/23/2015 & - & - & 19 \\
\hline $07 / 24 / 2015$ & - & $17 / 12$ & 44 \\
\hline $07 / 26 / 2015$ & 124 & $14 / 12$ & 24 \\
\hline 07/29/2015 & - & - & 42 \\
\hline $07 / 30 / 2015$ & 97 & $9 / 6$ & 32 \\
\hline $07 / 31 / 2015$ & 113 & $10 / 4$ & 22 \\
\hline $08 / 02 / 2015$ & 95 & $12 / 7$ & 32 \\
\hline 08/04/2015 & 90 & $16 / 8$ & 41 \\
\hline 08/06/2015 & 88 & $10 / 5$ & 19 \\
\hline 08/08/2015 & 102 & $7 / 3$ & 26 \\
\hline 08/10/2015 & 95 & $15 / 10$ & 24 \\
\hline 08/12/2015 & - & - & 37 \\
\hline 08/13/2015 & 58 & - & 36 \\
\hline 08/17/2015 & 25 & - & 65 \\
\hline 08/20/2015 & 10 & - & 14 \\
\hline $08 / 21 / 2015$ & 0 & - & 0 \\
\hline
\end{tabular}


females and 2 August for $\mathrm{H}_{\mathrm{p}}$ females. Despite differences in median run timing, hatchery strays were present on the spawning grounds during $92 \%$ of the surveys.

\section{Body length, body depth, and snout length}

The body length of individuals entering the creek declined over the course of the spawning season, but even so, $\mathrm{H}_{\mathrm{p}}$ males were on average $10 \%$ smaller than $\mathrm{N}_{\mathrm{o}}$ males after controlling for effects of date (Fig. 3A, Table 2; ANCOVA, $F=56.52$, df $=222$, p $<0.001$ ). Similarly, the body length of $\mathrm{H}_{\mathrm{p}}$ females was $6 \%$ smaller than the average $\mathrm{N}_{0}$ female after controlling for date of recovery (Fig. 3B; ANCOVA, $F=69.49$, df = 324, $\mathrm{p}<0.001)$.

Body depth of live male chum salmon entering the creek did not change throughout the season (ANCOVA, $F=0.45, \mathrm{p}=0.50$ ) and did not differ between groups (Table 2; ANOVA, $F=0.071$, df $=62$, $\mathrm{p}=0.79$ ). Similarly, female body depths did not vary through the spawning season (ANCOVA; $F=2.001$, $\mathrm{p}=0.16)$ and there were no differences between $\mathrm{N}_{\mathrm{o}}$ or $\mathrm{H}_{\mathrm{p}}$ females (Table 2; ANOVA, $F=0.98$, df $=48$, $\mathrm{p}=0.32$ ).

Snout length did not vary by entry date for males (ANCOVA, $F<0.01, \mathrm{p}=0.98$ ) or females (ANCOVA, $F=1.33, \mathrm{p}=0.25)$. Snout lengths of males did not differ between $\mathrm{H}_{\mathrm{p}}$ and $\mathrm{N}_{\mathrm{o}}$ groups (Table 2; ANOVA, $F=$ 0.04 , df $=62, \mathrm{p}=0.84$ ); however, snout lengths did differ significantly between females, with snouts of

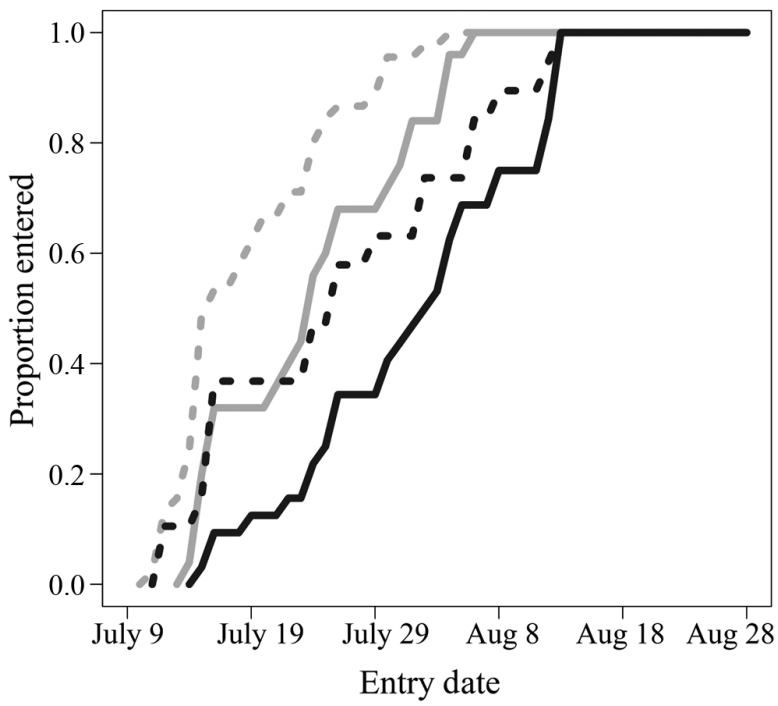

Fig. 2. Cumulative proportion of chum salmon entering Sawmill Creek across the 2015 spawning season. Dashed lines: males; solid lines: females. Grey: natural-origin salmon; black: hatchery-produced salmon
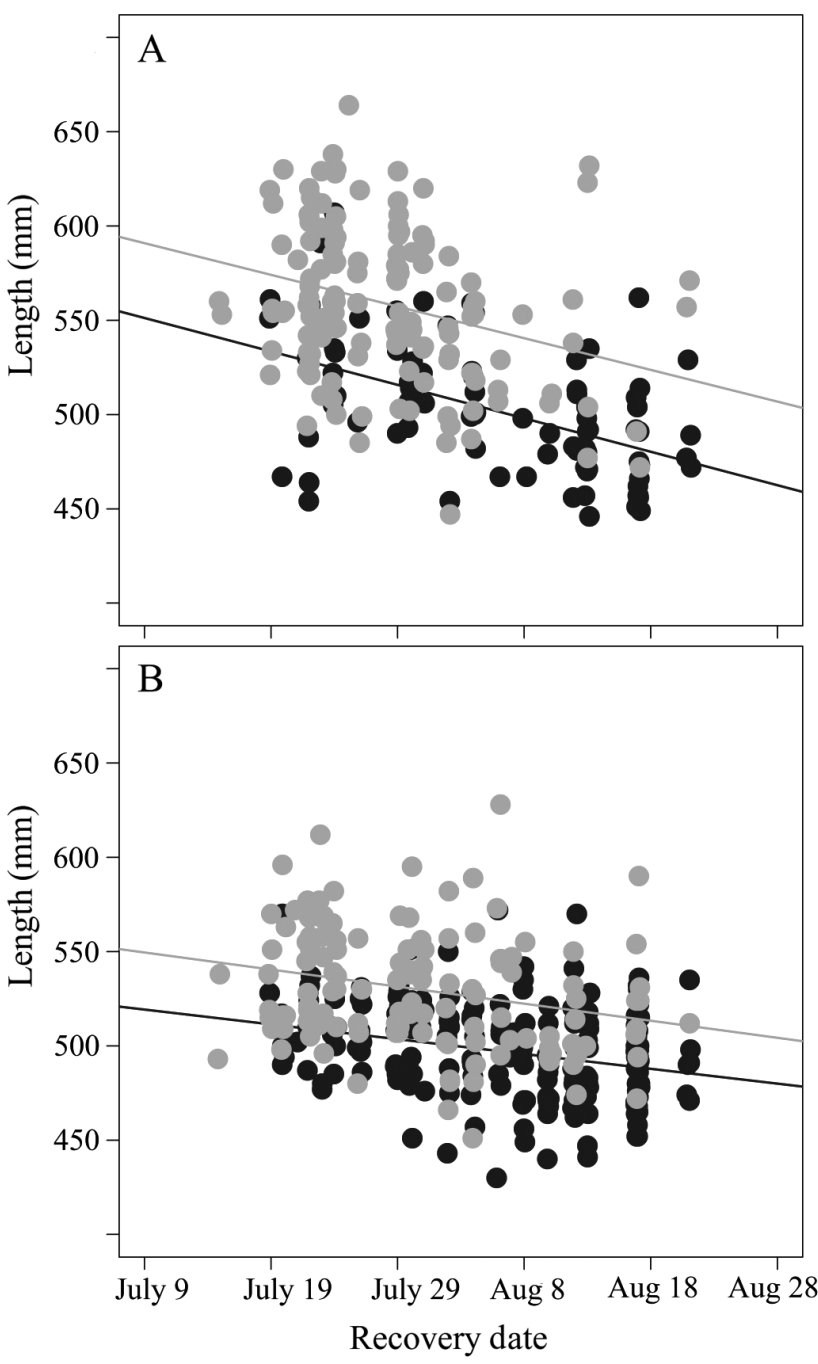

Fig. 3. Body lengths (measured from mid-eye to end of hypural plate, in $\mathrm{mm}$ ) of (A) male and (B) female chum salmon by recovery date in 2015. Grey: natural-origin salmon; black: hatchery-produced salmon. Solid lines: simple linear regressions through group

$\mathrm{N}_{\mathrm{o}}$ females being approximately $4 \%$ smaller than those of $\mathrm{H}_{\mathrm{p}}$ females (Table 2; ANOVA, $F=4.87, \mathrm{df}=$ $55, \mathrm{p}=0.03)$.

\section{Age at maturity}

Age at maturity was significantly younger for $\mathrm{H}_{\mathrm{p}}$ males (Kruskal-Wallis, $\chi^{2}=10.39$, df $=1, \mathrm{p}=0.001$ ) and females (Kruskal-Wallis, $\chi^{2}=10.51$, df $=1$; p < $0.001)$ than their naturally occurring counterparts. $\mathrm{H}_{\mathrm{p}}$ males primarily matured at $4 \mathrm{yr}$ of age $(79 \%)$ whereas age at maturity of $\mathrm{N}_{\mathrm{o}}$ males was evenly split between age- 4 and age-5 (Table 3). The proportion of $\mathrm{N}_{\mathrm{o}}$ females that matured at age- 4 was greater than 
Table 2. Mean trait values for groups of hatchery-produced $\left(\mathrm{H}_{\mathrm{p}}\right)$ and natural-origin $\left(\mathrm{N}_{\mathrm{o}}\right)$ chum salmon of both sexes, with SD in parentheses and sample sizes italicized. Unit for entry date is day of year (where Day 200 corresponds to 19 July); mid-eye

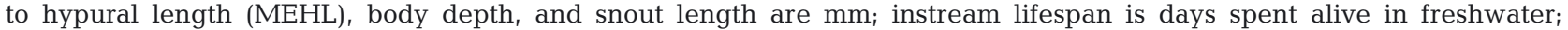
egg retention is proportion of eggs remaining in body cavity after natural death (range for both wild and female egg retention was 0.0 to 1.0 )

\begin{tabular}{|lclccccc|}
\hline Sex & Origin & Entry date & MEHL & Body depth & Snout length & Instream lifespan & Egg retention \\
\hline $\mathrm{M}$ & $\mathrm{N}_{\mathrm{o}}$ & $200(6.3) 45$ & $559(41) 138$ & $152(9) 45$ & $84(6) 45$ & $8.3(1.9) 45$ \\
$\mathrm{M}$ & $\mathrm{H}_{\mathrm{p}}$ & $207(10.7) 19$ & $502(35) 86$ & $151(6) 19$ & $83(7) 19$ & $7.5(2.3) 19$ & \\
$\mathrm{~F}$ & $\mathrm{~N}_{\mathrm{o}}$ & $205(7.6) 25$ & $529(32) 128$ & $130(7) 25$ & $54(4) 25$ & $8.1(2.1) 21$ & $0.18(0.33) 128$ \\
$\mathrm{~F}$ & $\mathrm{H}_{\mathrm{p}}$ & $213(9.2) 32$ & $497(25) 199$ & $132(8) 32$ & $56(4) 32$ & $5.8(1.9) 30$ & $0.43(0.40) 199$ \\
\hline
\end{tabular}

Table 3. Mean mid-eye to hypural length (MEHL, mm; with $\mathrm{SD}$ in parentheses) by age and sample sizes (n) for groups of hatchery-produced $\left(\mathrm{H}_{\mathrm{p}}\right)$ and natural-origin $\left(\mathrm{N}_{\mathrm{o}}\right)$ chum salmon of both sexes in dominant age classes (yr)

\begin{tabular}{|lcccr|}
\hline Age & Sex & Origin & MEHL & $\mathrm{n}$ \\
\hline 4 & $\mathrm{M}$ & $\mathrm{N}_{\mathrm{o}}$ & $548(43)$ & 58 \\
4 & $\mathrm{M}$ & $\mathrm{H}_{\mathrm{p}}$ & $496(29)$ & 63 \\
5 & $\mathrm{M}$ & $\mathrm{N}_{\mathrm{o}}$ & $568(37)$ & 61 \\
5 & $\mathrm{M}$ & $\mathrm{H}_{\mathrm{p}}$ & $517(45)$ & 17 \\
4 & $\mathrm{~F}$ & $\mathrm{~N}_{\mathrm{o}}$ & $523(32)$ & 72 \\
4 & $\mathrm{~F}$ & $\mathrm{H}_{\mathrm{p}}$ & $492(21)$ & 157 \\
5 & $\mathrm{~F}$ & $\mathrm{~N}_{\mathrm{o}}$ & $539(26)$ & 42 \\
5 & $\mathrm{~F}$ & $\mathrm{H}_{\mathrm{p}}$ & $515(31)$ & 32 \\
\hline
\end{tabular}

the proportion that matured at age-5 (63 and 37\%, respectively); however, a markedly higher proportion of $\mathrm{H}_{\mathrm{p}}$ females matured at age-4 than at age-5 (82 and $18 \%$, respectively; Table 3 ).

\section{Length at age}

$\mathrm{N}_{\mathrm{o}}$ individuals were significantly longer than their $\mathrm{H}_{\mathrm{p}}$ counterparts after controlling for date of recovery (Table 2) in both age-4 males ( 9.4\% longer; ANCOVA, $F=29.89$, df $=119, \mathrm{p}<0.001)$ and age-5 males ( 8.9\% longer; ANCOVA, $F=6.84, \mathrm{df}=75, \mathrm{p}=$ 0.01). Age- $4 \mathrm{~N}_{\mathrm{o}}$ females were longer than $\mathrm{H}_{\mathrm{p}}$ females after controlling for date of recovery $(\sim 5.9 \%$ longer; ANCOVA, $F=48.23$, df $=226, \mathrm{p}<0.001)$, as were age-5 $\mathrm{N}_{\mathrm{o}}$ females ( 4.4\% longer; ANCOVA, $F=8.88$, $\mathrm{df}=71, \mathrm{p}=0.003)$.

\section{Instream lifespan}

The instream lifespan of males did not differ significantly between $\mathrm{H}_{\mathrm{p}}(7.5 \pm 2.3 \mathrm{~d})$ and $\mathrm{N}_{\mathrm{o}}(8.3 \pm 1.9 \mathrm{~d})$ chum salmon (Table 2; ANCOVA, $F=1.29$, df $=61$, $\mathrm{p}=0.26)$. Conversely, $\mathrm{N}_{\mathrm{o}}$ females lived approximately $28 \%$ longer $(8.1 \pm 2.1$ d compared to $5.8 \pm$
$1.9 \mathrm{~d}$ ) than $\mathrm{H}_{\mathrm{p}}$ females (Table 2; ANCOVA, $F=6.94$, $\mathrm{df}=48, \mathrm{p}=0.01$ ).

\section{Egg retention}

Mean egg retention rates increased overall as the spawning season progressed (Fig. 4). Rates did not differ significantly between $\mathrm{N}_{\mathrm{o}}$ or $\mathrm{H}_{\mathrm{p}}$ females when controlling for the effect of death date (GLM, $Z=$ $-1.32, \mathrm{df}=168, \mathrm{p}=0.18)$. Overall, and apparently due to differences in arrival timing, $\mathrm{N}_{\mathrm{o}}$ females retained an average of $19 \%$ of their eggs whereas $\mathrm{H}_{\mathrm{p}}$ females averaged $47 \%$ egg retention (Table 2 ), though retention rates of both groups ranged from 0 to $100 \%$.

\section{DISCUSSION}

The interactions between $\mathrm{N}_{\mathrm{o}}$ and $\mathrm{H}_{\mathrm{p}}$ fish on spawning grounds have been a long-standing conservation focus (Waples 1991, McGinnity et al. 2003, Rand et al. 2012). The magnitude of potential genetic impacts is expected to grow with increasing divergence between phenotypes of strays and the recipient populations (Hendry 2004, Fraser et al. 2010, Peterson et al. 2014). Given that observed stray rates in Sawmill Creek have been consistently high when sampled (Josephson 2010, Piston \& Heinl 2012), and that nearby releases of similar magnitude have occurred for nearly $28 \mathrm{yr}$ (roughly 5 to 8 generations), there has been ample opportunity for genetic and ecological interactions between $\mathrm{N}_{o}$ and $\mathrm{H}_{\mathrm{p}}$ salmon to occur. Despite the potential for genetic introgression and homogenization of traits, we found consistent differences between $\mathrm{N}_{\mathrm{o}}$ and $\mathrm{H}_{\mathrm{p}}$ chum salmon in phenotypes with typically high heritability in salmonids (Carlson \& Seamons 2008). Our results suggest particularly strong differences in entrance timing, body length, age at maturity, and length at age. These differences could reflect barriers to introgression in the 


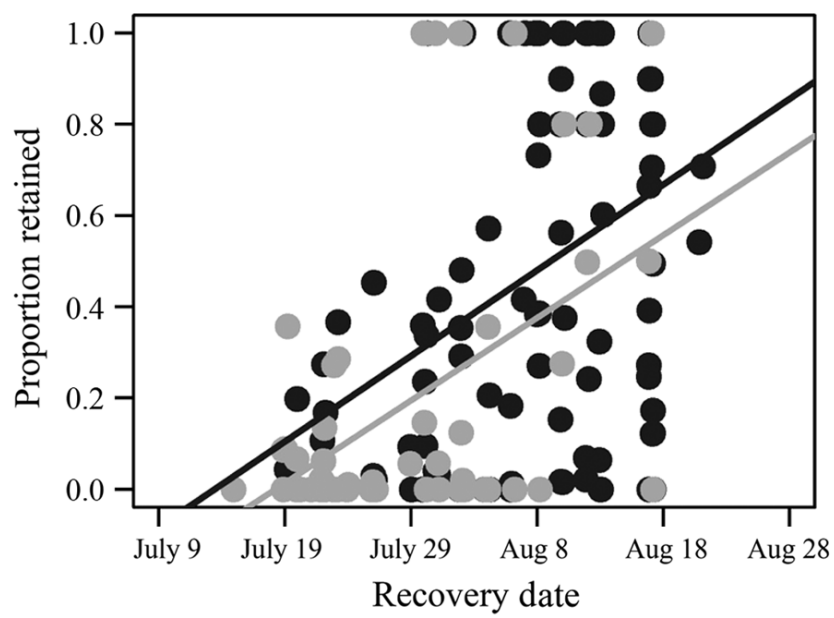

Fig. 4. Proportion of eggs retained by natural-origin (grey) and hatchery-produced (black) female chum salmon across the 2015 breeding season

form of pre-zygotic reproductive, selection against strays on the spawning grounds, reduced survival of hybrid offspring, and/or a considerable role for the environment (i.e. phenotypic plasticity) to shape these traits.

This study is the first to document phenotypic differences between $\mathrm{N}_{\mathrm{o}}$ and $\mathrm{H}_{\mathrm{p}}$ chum salmon on spawning grounds, suggesting that there is potential for erosion of local adaptation. Furthermore, the data collected here provide higher-resolution information on run timing and interaction potential than previous carcass surveys on Sawmill Creek, which were conducted periodically or once per spawning season. Other aspects related to the hatchery component found in Sawmill Creek that are pertinent to this study are that (1) the $H_{p}$ salmon found straying into Sawmill Creek are in part derived from the naturally occurring Sawmill Creek population at the onset of DIPAC broodstock development, (2) DIPAC broodstock has essentially been propagated as a segregated stock since development, and (3) all interactions on the spawning grounds between $\mathrm{H}_{\mathrm{p}}$ and $\mathrm{N}_{\mathrm{o}}$ salmon are unwanted by state salmon management. These conditions, when combined with the findings of this study, highlight the complexity of interpretation of results and further emphasize the need for indepth studies when investigating interaction potential of $H_{p}$ and $N_{o}$ salmon in wild systems.

\section{Entrance timing}

Typical of salmon migrations (Morbey 2000), males arrived first to Sawmill Creek, followed by females.
The timing of arrival, however, was staggered such that $\mathrm{N}_{\mathrm{o}}$ males arrived first, followed by $\mathrm{N}_{\mathrm{o}}$ females and $\mathrm{H}_{\mathrm{p}}$ males (whose median arrival day was only 3 $\mathrm{d}$ after the median $\mathrm{N}_{\mathrm{o}}$ female arrival day). On average, $H_{p}$ females arrived last on the spawning grounds. This contrasts with Prince William Sound, Alaska, where $\mathrm{H}_{\mathrm{p}}$ chum salmon arrived to spawning grounds prior to $\mathrm{N}_{\mathrm{o}}$ chum salmon, possibly due to selection of early-returning populations for broodstock (Brenner et al. 2012). Additionally, intensive fishing pressures in northern Southeast Alaska may have created directional selection on timing of freshwater entrance and spawning of $\mathrm{H}_{\mathrm{p}}$ and $\mathrm{N}_{\mathrm{o}}$ salmon differently (Quinn et al. 2007b). These caveats highlight that differences in run timing are likely site- and region-specific, making discussions difficult. In our study, the situation may be further complicated by initial brood collection requirements that necessitated early-returning salmon to successfully escape before surplus could be collected for broodstock development (B. Merideth, DIPAC, pers. comm.). Risk of interaction between $\mathrm{N}_{\mathrm{o}}$ spawners and $\mathrm{H}_{\mathrm{p}}$ strays may be mitigated within some systems by artificial selection for run timing within hatcheries or spatial segregation (Mackey et al. 2001, Williamson et al. 2010). Spatial isolation of spawning areas within Sawmill Creek is unlikely, given that all chum salmon spawning took place within a $300 \mathrm{~m}$ section of the $500 \mathrm{~m}$ of accessible habitat. Complete temporal isolation of $\mathrm{N}_{\mathrm{o}}$ Sawmill Creek chum salmon is similarly unlikely as $\mathrm{H}_{\mathrm{p}}$ strays were present on the spawning grounds during $92 \%$ of the surveys and male salmon remain reproductively active during their entire stream life.

Despite overlaps in time and space, there remain distinct entrance timing differences between $\mathrm{N}_{\mathrm{o}}$ and $\mathrm{H}_{\mathrm{p}}$ strays. Unfortunately, the historic entrance timing of Sawmill Creek chum salmon prior to start of nearby hatchery releases is unknown. It is also unknown if $\mathrm{H}_{\mathrm{p}}$ strays found in Sawmill Creek first arrive at their marine release locations (likely Amalga or Boat harbors), fail to find suitable spawning habitat, and then disperse to nearby creeks, which would mask their true arrival timing. Regardless of the mechanism, later arrival and spawning of $\mathrm{H}_{\mathrm{p}}$ strays likely affects their reproductive success and could influence the reproductive success of $\mathrm{N}_{0}$ salmon. Male $\mathrm{N}_{\mathrm{o}}$ salmon may be at a competitive disadvantage when examining entrance timing alone given that late-arriving $\mathrm{H}_{\mathrm{p}}$ males appeared to have access to many of the remaining females of both origins with little competition from $\mathrm{N}_{\mathrm{o}}$ males. For example, after 4 August (the latest confirmed entry date by a $\mathrm{N}_{\mathrm{o}}$ 
male) there were only $16 \mathrm{~N}_{0}$ male carcasses collected, while there were $44 \mathrm{H}_{\mathrm{p}}$ males collected, as well as $124 \mathrm{H}_{\mathrm{p}}$ and $36 \mathrm{~N}_{\mathrm{o}}$ females.

In order to successfully spawn, a late-arriving female must attempt to displace females already in choice locations, wait for nest-guarding females to die, or choose a less desirable location (reviewed in Fleming \& Reynolds 2003). Prior residency is a key factor in the successful defense of a redd (nest) location from invasion, even from larger females (Foote 1990). In Sawmill Creek, $H_{p}$ females generally had later arrival dates (and smaller body size), which would likely put them at a competitive disadvantage when attempting to secure a spawning location.

\section{Body length, body depth, and snout length}

Salmon populations commonly experience divergent regimes of natural and sexual selection based on the environmental pressures of a discrete stock (Quinn et al. 2001). For example, male sockeye salmon spawning in the relative absence of bird or bear predators and with no stranding risk in shallow water (e.g. lake spawners) tend to be deep-bodied (Quinn \& Foote 1994), whereas shallow-body phenotypes are favored in creek-spawning populations where risk of predation and stranding is high (Quinn \& Buck 2001, Carlson et al. 2009). When subjected to high rates of bear predation, salmon with smaller body lengths tend to have increased relative reproductive success (Lin et al. 2016). Predation on chum salmon in Sawmill Creek was low in 2015 (58 chum salmon deaths attributed to bear predation out of 558 positively identified causes of death), likely due to the high abundance of pink salmon, which were approximately 2 orders of magnitude more abundant than chum salmon. Additionally, the creek was sufficiently deep such that stranding was not an appreciable risk (only 1 salmon died of stranding as tide receded). Therefore, we expect that large and deep body depth might be favored through sexual selection in Sawmill Creek. However, we observed no significant differences between $\mathrm{N}_{o}$ or $\mathrm{H}_{\mathrm{p}}$ males or females for either trait. We found a small difference in snout length between females, where $H_{p}$ females had larger size-adjusted snout lengths compared to $\mathrm{N}_{\mathrm{o}}$ counterparts. Size of secondary sexual characteristics such as jaw size can relate to migration distance (Kinnison et al. 2003); however, all sources of DIPAC broodstock are from populations with comparably short migrations. We acknowledge that this result, while curious, is potentially spurious.
We found that $\mathrm{N}_{\mathrm{o}}$ chum salmon of both sexes were significantly longer than $\mathrm{H}_{\mathrm{p}}$ chum salmon throughout the spawning season, which might benefit $\mathrm{N}_{\mathrm{o}}$ individuals in competitive interactions. Male dominance is strongly correlated with size and prior access to females, and dominant male chum salmon usually sire a higher proportion of offspring than satellite males (Schroder 1982, Foote 1990, Fleming \& Gross 1994, Berejikian et al. 2009). Therefore, established and larger $\mathrm{N}_{\mathrm{o}}$ males should have higher reproductive success than late-coming and smaller $\mathrm{H}_{\mathrm{p}}$ males.

Being large-bodied (and thus more conspicuous) likely had little negative impact on the reproductive success of females chum salmon in Sawmill Creek, because most females killed by bears were killed after spawning had occurred, negating any fitness consequences of being large (Quinn \& Kinnison 1999, Lin et al. 2016), likely due to the difficulty of bears catching newly entered fish in the fast-flowing stream (Gende et al. 2004). Also, abundant pink salmon appeared to buffer the less abundant chum salmon from predation, and thus bears seem an unlikely agent of selection in this system. In the absence of strong selection against large females through predation, the relative reproductive success of larger females should then be higher than smaller females through a combination of preferential access to spawning sites, ease of redd defense, ability to attain greater egg burial depth, and greater fecundity (van den Berghe \& Gross 1984, Steen \& Quinn 1999). However, selection direction and intensity is not always constant (Ford et al. 2008, Lin et al. 2016) and small females may be able to utilize spawning areas not available or optimal for large females (van den Berghe \& Gross 1984). Additionally, if redd superimposition caused by late returning $\mathrm{H}_{\mathrm{p}}$ females was common and occurred prior to sensitive developmental stages of $\mathrm{N}_{\mathrm{o}}$ embryos, the relative reproductive success of the early-spawning (and typically larger) $\mathrm{N}_{\mathrm{o}}$ females could be reduced (Gharrett et al. 2013).

\section{Age and length at maturity}

$\mathrm{H}_{\mathrm{p}}$ males and females matured younger and were less variable in age than $\mathrm{N}_{\mathrm{o}}$ chum salmon. Similar differences in age at maturity and age structure between natural and hatchery populations have been found in Atlantic and Pacific salmon populations and have mainly been attributed to fishery selection, different growth trajectories, and within-hatchery effects (Knudsen et al. 2006, Imai et al. 2007, Ford et al. 2012, Zaporozhets \& Zaporozhets 2012). 
Fishery selection that causes age-at-maturity declines is more likely to occur in fisheries that target multiple maturity stages (Healey 1986, Kuparinen \& Merilä 2007). Chum salmon in northern Southeast Alaska are commercially harvested with gill nets and purse seines (Gray et al. 2016) and on a smaller scale by trolling (Skannes et al. 2016). Although these harvest methods do have size-selective potential (Milne 1955, Kendall \& Quinn 2012), they only target mature adult individuals. It is possible, but unknown given the available data, that the largest $\mathrm{H}_{\mathrm{p}}$ fish are selectively caught, leaving the smaller, younger fish to potentially stray and skew observed age-at-maturity observations made in Sawmill Creek. However, it is unlikely that fishery selection targets $H_{p}$ and not $N_{o}$ salmon given the close proximity of Sawmill Creek to terminal harvest areas and unknown migratory pathways taken by either group.

In many species of salmon, rapid growth tends to be associated with younger age at maturity (Myers et al. 1986, Nicieza \& Braña 1993, Vollestad et al. 2004, Morita et al. 2005, Claiborne et al. 2011) and accelerated growth in the hatchery and release at a large size may underpin the pattern of maturing younger by $\mathrm{H}_{\mathrm{p}}$ chum salmon. To increase their size prior to release with the goal of increasing survival rates, $\mathrm{H}_{\mathrm{p}}$ chum salmon are fed for several months following emergence (A. Zaleski, DIPAC pers. comm.). Consequently, hatchery chum salmon released in northern Southeast Alaska are larger and more energy-dense than newly emigrated wild chum salmon (Reese et al. 2008), but when sampled several weeks later in areas along their shared migratory pathway towards the Gulf of Alaska, their size and energy densities were similar (Sturdevant et al. 2012). Several weeks later in the eastern Gulf of Alaska, $N_{0}$ chum salmon had a larger mean length (Kohan et al. 2013) suggesting either compensatory growth by the $\mathrm{N}_{\mathrm{o}}$ fish, selective mortality against the fastest growing $\mathrm{H}_{\mathrm{p}}$ fish, or a combination of the two. Though dietary differences as juveniles may temporarily interrupt growth trajectories, Morita \& Fukuwaka (2006) found that chum salmon maturity schedules were more closely linked to growth rates during later growth stages (specifically, the growth season prior to maturity and spawning), so differences early in life may not adequately explain different body lengths or age at maturity.

The different patterns of maturation between $\mathrm{H}_{p}$ and $\mathrm{N}_{\mathrm{o}}$ chum salmon found in Sawmill Creek may alternatively reflect trade-offs between size and maturation. Attaining a large size that would be favored during natural spawning comes at the cost of longer growth period or heightened feeding rates, both of which incur additional mortality risks (Walters \& Juanes 1993, Tillotson \& Quinn 2016). In the absence of fitness benefits associated with large body size experienced in natural populations, less time at sea may be the favored life history tactic of $\mathrm{H}_{\mathrm{p}}$ salmon (Gross 1985), which could explain the lower age at maturity observed of $\mathrm{H}_{\mathrm{p}}$ chum salmon found in Sawmill Creek.

Furthermore, $\mathrm{H}_{\mathrm{p}}$ males and females were less variable in age at maturity, a heritable trait (Carlson \& Seamons 2008), and returns were dominated by age- 4 fish. Complex age structures act as a buffer against environmental variability and act as a stabilizer of population size (Moore et al. 2014) and positively influence population productivity (Greene et al. 2010). However, in this instance, being less variable in age structure may make hatchery populations more prone to 'boom and bust' cycles which could increase and decrease numerical interaction potential in some years.

Paradoxically, the smaller size at age of $\mathrm{H}_{\mathrm{p}}$ fish suggests slower growth in the marine environment, yet the younger age at maturation usually correlates with a period of rapid growth (Morita \& Fukuwaka 2006). A possible scenario that explains our findings is that rapid growth within the hatchery environment puts $\mathrm{H}_{\mathrm{p}}$ chum salmon on a trajectory to mature young but leads to domestication effects that may either (1) expose the fastest growing and more aggressive juveniles to higher predation related mortality once released (Yamamoto \& Reinhardt 2003), or (2) cause a lag in transition to wild food types which slows growth potential (Sturdevant et al. 2012). Regardless of causality, disparities in size and age at maturity between chum salmon of different origins may have consequences for long-term reproductive success of the $\mathrm{N}_{\mathrm{o}}$ population if genetic introgression or sizemediated competition occurs. $\mathrm{H}_{\mathrm{p}}$ females on average were smaller for their age than $\mathrm{N}_{\mathrm{o}}$ chum, which could negatively affect the overall fecundity of hybrids, as well as impact their ability to build and protect redds (van den Berghe \& Gross 1984).

\section{Instream lifespan}

Instream lifespans of both sexes decreased as the spawning season progressed, consistent with other observations in semelparous salmon breeding systems (McPhee \& Quinn 1998, Hendry et al. 2004, Dickerson et al. 2005, Doctor \& Quinn 2009). For males, the difference in lifespan of one day was not statistically significant, though it could be biologically significant given that males can continue to spawn throughout their freshwater lifespans and that 
additional breeding opportunities decline non-linearly given changes in the operational sex ratio (Dickerson et al. 2005). In contrast, $\mathrm{N}_{\mathrm{o}}$ females lived significantly longer in freshwater than did $\mathrm{H}_{\mathrm{p}}$ females, which would provide a competitive advantage when vying for quality spawning locations or guarding redds from other females (McPhee \& Quinn 1998, Hendry et al. 2004). In fact, our observations of the entirety of Sawmill Creek revealed several preferred locations that female chum continually spawned in throughout the season, reinforcing the importance of female longevity and entrance timing when maximizing relative reproductive success.

\section{Egg retention}

While $\mathrm{H}_{\mathrm{p}}$ females retained roughly the same proportion of eggs when compared to $\mathrm{N}_{\mathrm{o}}$ females spawning at the same time, they retained more than twice the expected number of eggs than did $\mathrm{N}_{\mathrm{o}}$ females over the course of the spawning season. This may be due to $\mathrm{N}_{\mathrm{o}}$ chum salmon arriving and spawning prior to the peak pink salmon spawning activity, whereas the mean entry time of $\mathrm{H}_{\mathrm{p}}$ chum salmon was later, coinciding with peak pink salmon spawning activities and hence greatly increased competition for space (Sergeant et al. 2017). Once pink salmon spawning activities commenced in late July, the variability in egg retention increased in both $\mathrm{H}_{\mathrm{p}}$ and $\mathrm{N}_{\mathrm{o}}$ chum salmon. The spawning aggregations of pink salmon in Sawmill Creek during late July and early August 2015 were especially dense (min. density: 1 pink salmon $\mathrm{m}^{-2}$ ) and significantly overlapped the period of chum salmon spawning dates. Peak pink salmon abundance and $\mathrm{H}_{\mathrm{p}}$ chum arrival and spawning time coincided with periodic hypoxic conditions (Sergeant et al. 2017), a hypothesized contributor to egg retention and pre-spawn mortality (Tillotson \& Quinn 2016) which reinforces and emphasizes the potentially stark consequences of run timing (and prior residency) on reproductive success. These results suggest that egg retention (shaped by sex-specific run timing) may be a key factor limiting reproductive success of $\mathrm{H}_{\mathrm{p}}$ females on the spawning grounds (similar to findings by Fleming et al. 1996), though persistent prevalence of $\mathrm{H}_{\mathrm{p}}$ strays in high proportions may compensate for lower reproductive success.

\section{CONCLUSIONS AND IMPLICATIONS}

The proposed thresholds at which a population can maintain integrity of heritable traits and thereby resist outbreeding depression assume a single fixed proportion of $\mathrm{H}_{\mathrm{p}}$ spawners to $\mathrm{N}_{\mathrm{o}}$ spawners during a spawning season, and do not account for unequal reproductive success. In Sawmill Creek, the thresholds of $5 \% \mathrm{H}_{\mathrm{p}}$ spawners suggested by Mobrand et al. (2005) and $10 \%$ suggested by Ford (2002) bracket an instream estimate of $8 \% \mathrm{H}_{\mathrm{p}}$ spawners in 1995, and were greatly exceeded in 1996, 2009, 2010, and 2015 with estimates of $78,78,47$, and $51 \%$, respectively (Josephson 2010, Piston \& Heinl 2012). The 1995, 1996, and 2009 estimates were from one day of sampling while samples from 2010 were collected during 3 separate visits. During the intensive sampling that occurred during 2015, it was evident that the proportion of $\mathrm{H}_{\mathrm{p}}$ chum salmon in Sawmill Creek changed through time, and suggests that $\mathrm{N}_{\mathrm{o}}$ fish entering early may be less likely to be impacted by introgression based on low $\mathrm{H}_{\mathrm{p}}$ proportions present at that time. However, near the later portion of the run very few $\mathrm{N}_{\mathrm{o}}$ males were being collected as carcasses whereas numerous $\mathrm{H}_{\mathrm{p}}$ males and $\mathrm{N}_{\mathrm{o}}$ females (with known egg retention rates) were being recovered, indicating a higher potential for hybridization in the later stages of the spawning season. Furthermore, differences in traits such as body size, lifespan, and egg retention undermine the assumption of equal reproductive success in proposed thresholds. In Sawmill Creek during 2015, these differences generally favored the $\mathrm{N}_{\mathrm{o}}$ over $\mathrm{H}_{\mathrm{p}}$ chum salmon in terms of relative reproductive performance. However, it is conceivable that in other $\mathrm{N}_{\mathrm{o}}$ populations relative reproductive success may favor $\mathrm{H}_{\mathrm{p}}$ strays and proportions of 5 or $10 \%$ may be sufficient to allow for substantial genetic introgression. Ultimately, our study underscores the utility of combining purely ecological work with genetic studies of reproductive success or introgression (e.g. see Jasper et al. 2013) to provide greater understanding of the barriers and bridges to reproductive isolation in nature.

Acknowledgements. Fish handling was permitted and approved by University of Alaska Fairbanks IACUC (\#726223) and ADF\&G Fish Resource Permit (SF2015-183). This project was funded through the Ladd Macaulay Graduate Fellowship, the Northern Gulf of Alaska Applied Research Grant, and by the University of Alaska Foundation startup funds to P.A.H.W. Special thanks to Eric Prestegard, Brock Meredith, Adam Zaleski, and Charlie Currit who provided clarification on discussion points and facilitated collection of specimens from DIPAC as well as the ADF\&G Mark Tag and Age Lab staff and supervisors for generous use of lab space, equipment, and the wisdom of the otolith experts who advised and assisted with thermal mark identification. Collection of field data could not have been possible without Jenell Larsen. Study design and data inter- 
pretation were improved through consideration of comments by Eric Knudsen, Alex Wertheimer, Ron Josephson, and Samuel Rabung. Additionally, the manuscript was improved through valuable revisions by Dion Oxman and Shannon Atkinson and anonymous reviewers.

\section{LITERATURE CITED}

Araki H, Cooper B, Blouin MS (2007) Genetic effects of captive breeding cause a rapid, cumulative fitness decline in the wild. Science 318:100-103

Beacham TD, Murray CB (1993) Fecundity and egg size variation in North American Pacific salmon (Oncorhynchus). J Fish Biol 42:485-508

Berejikian BA, Van Doornik DM, Scheurer JA, Bush R (2009) Reproductive behavior and relative reproductive success of natural-and hatchery-origin Hood Canal summer chum salmon (Oncorhynchus keta). Can J Fish Aquat Sci 66:781-789

Bett NN, Hinch SG, Burnett NJ, Donaldson MR, Naman SM (2017) Causes and consequences of straying into small populations of Pacific salmon. Fisheries (Bethesda, Md) 42:220-230

Bilton HT, Jenkinson DW (1968) Comparison of the otolith and scale methods for aging sockeye (Oncorhynchus nerka) and chum (O. keta) salmon. J Fish Res Board Can 25:1067-1069

Bolstad GH, Hindar K, Robertsen G, Jonsson B and others (2017) Gene flow from domesticated escapes alters the life history of wild Atlantic salmon. Nat Ecol Evol 1:0124

Brenner ER, Moffitt SD, Grant WS (2012) Straying of hatchery salmon in Prince William Sound, Alaska. Environ Biol Fishes 94:179-195

Carlson SM, Seamons TR (2008) A review of quantitative genetic components of fitness in salmonids: implications for adaptation to future change. Evol Appl 1:222-238

Carlson SM, Rich HB, Quinn TP (2009) Does variation in selection imposed by bears drive divergence among populations in the size and shape of sockeye salmon? Evolution 63:1244-1261

* Christie MR, Marine ML, French RA, Blouin MS (2012) Genetic adaptation to captivity can occur in a single generation. Proc Natl Acad Sci USA 109:238-242

Christie MR, Marine ML, Fox SE, French RA, Blouin MS (2016) A single generation of domestication heritability alters the expression of hundreds of genes. Nat Commun $7: 10676$

Claiborne AM, Fisher JP, Hayes SA, Emmett RL (2011) Size at release, size-selective mortality, and age of maturity of Willamette River hatchery yearling Chinook salmon. Trans Am Fish Soc 140:1135-1144

Clark JE, Weller JL (1986) Age, sex, and size of chum salmon (Oncorhynchus keta Walbaum) from catches and escapements in Southeastern Alaska, 1984. Technical Data Report, Alaska Department of Fish and Game, Juneau, AK

Consuegra S, Verspoor E, Knox D, García de Leániz C (2005) Asymmetric gene flow and the evolutionary maintenance of genetic diversity in small, peripheral Atlantic salmon populations. Conserv Genet 6:823-842

* Dickerson BR, Brinck KW, Willson MF, Bentzen P, Quinn TP (2005) Relative importance of salmon body size and arrival time at breeding grounds to reproductive success. Ecology 86:347-352
Doctor KK, Quinn TP (2009) Potential for adaptation-by-time in sockeye salmon (Oncorhynchus nerka): the interactions of body size and in-stream reproductive lifespan with date of arrival and breeding location. Can J Zool 87 : 708-717

Fernandez E, Moffitt S (2016) Otolith processing and quality control methods used by the ADF\&G Cordova Otolith Laboratory. Alaska Hatchery Research Group Technical Document \#12, Alaska Department of Fish and Game, Juneau, AK

Fleming IA, Einum S (1997) Experimental tests of genetic divergence of farmed from wild Atlantic salmon due to domestication. ICES J Mar Sci 54:1051-1063

Fleming IA, Gross MR (1989) Evolution of adult female life history and morphology in a Pacific salmon (coho: Oncorhynchus kisutch). Evolution 43:141-157

Fleming IA, Gross MR (1994) Breeding competition in a Pacific salmon (coho: Oncorhynchus kisutch): measures of natural and sexual selection. Evolution 48:637-657

Fleming IA, Reynolds JD (2003) Salmonid breeding systems. In: Hendry AP, Stearns SC (eds) Evolution illuminated: salmon and their relatives. Oxford University Press, Oxford, p 264-294

*Fleming IA, Jonsson B, Gross MR, Lamberg A (1996) An experimental study of the reproductive behavior and success of farmed and wild Atlantic salmon (Salmo salar). J Appl Ecol 33:893-905

Foerster RE (1937) The return from the sea of sockeye salmon (Oncorhynchus nerka) with special reference to percentage survival, sex proportions and progress of migration. J Biol Board Can 3:26-42

*FFoote CJ (1990) An experimental comparison of male and female spawning territoriality in Pacific salmon. Behaviour 115:283-314

FFord MJ (2002) Selection in captivity during supportive breeding may reduce fitness in the wild. Conserv Biol 16: 815-825

F Ford MJ, Hard JJ, Boelts B, LaHood E, Miller J (2008) Estimates of natural selection in a salmon population in captive and natural environments. Conserv Biol 22:783-794

F Ford MJ, Murdoch A, Howard S (2012) Early male maturity explains a negative correlation in reproductive success between hatchery-spawned salmon and their naturally spawning progeny. Conserv Lett 5:450-458

Frankham R (2008) Genetic adaptation to captivity in species conservation programs. Mol Ecol 17:325-333

F Fraser DJ, Minto C, Calvert AM, Eddington JD, Hutchings JA (2010) Potential for domesticated-wild interbreeding to induce maladaptive phenology across multiple populations of wild Atlantic salmon (Salmo salar). Can J Fish Aquat Sci 67:1768-1776

Fraser DJ, Weir LK, Bernatchez L, Hansen MM, Taylor EB (2011) Extent and scale of local adaptation in salmonid fishes: review and meta-analysis. Heredity 106: 404-420

*Gende SM, Quinn TP, Hilborn R, Hendry AP, Dickerson B (2004) Brown bears selectively kill salmon with higher energy content but only in habitats that facilitate choice. Oikos 104:518-528

* Gharrett AJ, Smoker WW (1991) Two generations of hybrids between even- and odd-year pink salmon (Oncorhynchus gorbuscha): A test for outbreeding depression? Can J Fish Aquat Sci 48:1744-1749

*Gharrett AJ, Smoker WW, Reisenbichler RR, Taylor SG (1999) Outbreeding depression in hybrids between odd- 
and even-brood year pink salmon. Aquaculture 173: $117-129$

* Gharrett AJ, Joyce J, Smoker W (2013) Fine scale temporal adaptation within a salmonid population: mechanism and consequences. Mol Ecol 22:4457-4469

Gray D, Gordon D, Harris D, Conrad S and others (2016) Annual management report of the 2015 Southeast Alaska commercial purse seine and drift gillnet fisheries. Fishery Management Report No. 16-10, Alaska Department of Fish and Game, Anchorage, AK

Greene CM, Hall JE, Guilbault KR, Quinn TP (2010) Improved viability of populations with diverse life-history portfolios. Biol Lett 6:382-386

Gross MR (1985) Disruptive selection for alternative life histories in salmon. Nature 313:47-48

Hasler AD, Wisby WJ (1951) Discrimination of stream odors by fishes and relation to parent stream behavior. Am Nat 85:223-238

Healey MC (1986) Optimum size and age at maturity in Pacific salmon and effects of size-selective fisheries. In: Meerburg DJ (ed) Salmonid age at maturity. Can Spec Publ Fish Aquat Sci 89, Ottawa, p 39-52

* Heggberget TG, Johnsen BO, Hindar K, Jonsson B, Hansen LP, Hvidsten NA, Jensen AJ (1993) Interactions between wild and cultured Atlantic salmon: a review of Norwegian experience. Fish Res 18:123-146

Hendry AP (2004) Selection against migrants contributes to the rapid evolution of ecologically dependent reproductive isolation. Evol Ecol Res 6:1219-1236

*Hendry AP, Berg OK (1999) Secondary sexual characters, energy use, senescence, and cost of reproduction in sockeye salmon. Can J Zool 77:1663-1675

*Hendry AP, Quinn TP (1997) Variation in adult life history and morphology among Lake Washington sockeye salmon (Oncorhynchus nerka) populations in relation to habitat features and ancestral affinities. Can J Fish Aquat Sci 54:75-84

Hendry AP, Wenburg JK, Bentzen P, Volk EC, Quinn TP (2000) Rapid evolution of reproductive isolation in the wild: evidence from introduced salmon. Science 290:516-518

*Hendry AP, Morbey YE, Berg OK, Wenburg JK (2004) Adaptive variation in senescence: reproductive lifespan in a wild salmon population. Proc R Soc B 271:259-266

Imai N, Sagawa Y, Kudo H, Kaeriyama M (2007) A comparison of secondary sexual characters and age composition of wild and hatchery chum salmon (Oncorhynchus keta) in the Yarappu River, southern Hokkaido in Japan. NPAFC Tech Rep 7115-116

Jasper JR, Habicht C, Moffitt S, Brenner R and others (2013) Source-sink estimates of genetic introgression show influence of hatchery strays on wild chum salmon populations in Prince William Sound, Alaska. PLOS ONE 8: e81916

Jonsson B, Jonsson N, Hansen LP (2003) Atlantic salmon straying from the River Isma. J Fish Biol 62:641-657

Josephson RP (2010) Observations of the distribution of hatchery chum salmon in Southeast Alaska, 1980-2006. Regional Information Report 5J10-07, Alaska Department of Fish and Game, Anchorage, AK

Kendall NW, Quinn TP (2012) Quantifying and comparing size selectivity among Alaskan sockeye salmon fisheries. Ecol Appl 22:804-816

Kinnison MT, Unwin MJ, Quinn TP (2003) Migratory costs and contemporary evolution of reproductive allocation in male Chinook salmon. J Evol Biol 16:1257-1269
Knudsen CM, Schroder SL, Busack CA, Johnston MV, Pearsons TN, Bosch WJ, Fast DE (2006) Comparison of life history traits between first-generation hatchery and wild upper Yakima River spring Chinook salmon. Trans Am Fish Soc 135:1130-1144

Kohan ML, Orsi JA, Muter F, McPhee MV (2013) Variation in abundance and condition of juvenile chum salmon (Oncorhynchus keta) in the eastern Gulf of Alaska in relation to environmental variables. NPAFC Tech Rep 9: 244-248

Kuparinen A, Merilä J (2007) Detecting and managing fisheries-induced evolution. Trends Ecol Evol 22:652-659

Leider S (1989) Increased straying by adult steelhead trout, Salmo gairdneri, following the 1980 eruption of Mount St. Helens. Environ Biol Fishes 24:219-229

* Lin JE, Hard JJ, Naish KA, Peterson D, Hilborn R, Hauser L (2016) It's a bear market: evolutionary and ecological effects of predation on two wild sockeye salmon populations. Heredity 116:447-457

* Mackey G, McLean JE, Quinn TP (2001) Comparisons of run timing, spatial distribution and length of wild and newly established hatchery population of steelhead in Forks Creek, Washington. N Am J Fish Manage 21:717-724

McClelland EK, Naish KA (2007) What is the fitness outcome of crossing unrelated fish populations? A metaanalysis and the evaluation of future research directions. Conserv Genet 8:397-416

* McClelland EK, Myers JM, Hard JJ, Park LK, Naish KA (2005) Two generations of outbreeding in coho salmon (Oncorhynchus kisutch): effects on size and growth. Can J Fish Aquat Sci 62:2538-2547

*McGinnity P, Prodohl P, Ferguson K, Hynes R and others (2003) Fitness reduction and potential extinction of wild populations of Atlantic salmon, Salmo salar, as a result of interactions with escaped farm salmon. Proc R Soc B 270: 2443-2450

McPhee MV, Quinn TP (1998) Factors affecting the duration of nest defense and reproductive lifespan of female sockeye salmon, Oncorhynchus nerka. Environ Biol Fishes 51:369-375

* McPhee MV, Whited DC, Kuzishchin KV, Stanford JA (2014) The effects of riverine physical complexity on anadromy and genetic diversity in steelhead or rainbow trout Oncorhynchus mykiss around the Pacific Rim. J Fish Biol 85:132-150

Milne DJ (1955) Selectivity of trolling lures. Fish Res Board Can Prog Rep Pac Coast Stns 103:3-5

*Mobrand LE, Barr J, Blankenship L, Campton DE and others (2005) Hatchery reform in Washington State: principles and emerging issues. Fisheries (Bethesda, Md) 30:11-39

*Moore JW, Yeakel JD, Peard D, Lough J, Beere M (2014) Life-history diversity and its importance to population stability and persistence of a migratory fish: steelhead in two large North American watersheds. J Anim Ecol 83: 1035-1046

* Morbey Y (2000) Protandry in Pacific salmon. Can J Fish Aquat Sci 57:1252-1257

*Morita K, Fukuwaka M (2006) Does size matter most? The effect of growth history on probabilistic reaction norm for salmon maturation. Evolution 60:1516-1521

*Morita K, Morita SH, Fukuwaka M, Matsuda H (2005) Rule of age and size at maturity of chum salmon (Oncorhynchus keta): implications of recent trends among Oncorhynchus spp. Can J Fish Aquat Sci 62:2752-2759

* Muhlfeld CC, Kalinowski ST, McMahon TE, Taper ML, 
Painter S, Leary RF, Allendorf FW (2009) Hybridization rapidly reduces fitness of a native trout in the wild. Biol Lett 5:328-331

* Myers RA, Hutchings JA, Gibson RJ (1986) Variation in male parr maturation within and among populations of Atlantic salmon, Salmo salar. Can J Fish Aquat Sci 43: 1242-1248

Naish KA, Taylor JE III, Levin PS, Quinn TP and others (2007) An evaluation of the effects of conservation and fishery enhancement hatcheries on wild populations of salmon. Adv Mar Biol 53:61-194

Nicieza AG, Braña F (1993) Relationships among smolt size, marine growth, and sea age at maturity of Atlantic salmon (Salmo salar) in northern Spain. Can J Fish Aquat Sci 50:1632-1640

Nielsen JL, Ruggerone GT, Zimmerman CE (2013) Adaptive strategies and life history characteristics in a warming climate: salmon in the Arctic? Environ Biol Fishes 96: 1187-1226

North Pacific Anadromous Fish Commission (NPAFC) (2016) NPAFC Pacific salmonid hatchery release statistics (updated 20 July 2016). North Pacific Anadromous Fish Commission, Vancouver. www.npafc.org (accessed 20 July 2016)

Pess GR, Hilborn R, Kloehn K, Quinn TP (2012) The influence of population dynamics and environmental conditions on pink salmon (Oncorhynchus gorbuscha) recolonization after barrier removal in the Fraser River, British Columbia, Canada. Can J Fish Aquat Sci 69:970-982

Peterson DA, Hilborn R, Hauser L (2014) Local adaptation limits lifetime reproductive success of dispersers in a wild salmon metapopulation. Nat Commun 5:3696

Piston AW, Heinl SC (2012) Hatchery chum salmon straying studies in Southeast Alaska, 2008-2010. Fishery Manuscript Series No. 12-01, Alaska Department of Fish and Game, Anchorage AK

Piston AW, Heinl SC (2014) Chum salmon stock status and escapement goals in Southeast Alaska. Special Publication No. 14-13, Alaska Department of Fish and Game, Anchorage, AK

* Quinn TP (1993) A review of homing and straying of wild and hatchery-produced salmon. Fish Res 18:29-44

Quinn TP (2005) The evolution and structure of salmon populations. In: Quinn TP (ed) The behavior and ecology of Pacific salmon and trout. American Fisheries Society, Bethesda, MD, p 299-316

* Quinn TP, Blair GR (1992) Morphological changes in senescing adult male sockeye salmon (Oncorhynchus nerka Walbaum). J Fish Biol 41:1045-1047

Q Quinn TP, Buck GB (2001) Size- and sex-selective mortality of adult sockeye salmon: bears, gulls, and fish out of water. Trans Am Fish Soc 130:995-1005

Quinn TP, Foote CJ (1994) The effects of boxy size and sexual dimorphism on the reproductive behavior of sockeye salmon, Oncorhynchus nerka. Anim Behav 48:751-761

* Quinn TP, Kinnison M (1999) Size-selective and sex-selective predation by brown bears on sockeye salmon. Oecologia 121:273-282

Quinn TP, Hendry AP, Buck GB (2001) Balancing natural and sexual selection in sockeye salmon: interactions between body size, reproductive opportunity and vulnerability to predation by bears. Evol Ecol Res 3:917-937

Quinn TP, Eggers DM, Clark JH, Rich HB (2007a) Density, climate, and the processes of prespawning mortality and egg retention in Pacific salmon (Oncorhynchus spp.).
Can J Fish Aquat Sci 64:574-582

* Quinn TP, Hodgson S, Flynn L, Hilborn R, Rogers DE (2007b) Directional selection by fisheries and the timing of sockeye salmon (Oncorhynchus nerka) migrations. Ecol Appl 17:731-739

Rand PS, Berejikian BA, Pearsons TN, Noakes DLG (2012) Ecological interactions between wild and hatchery salmonids: an introduction to the special issue. Environ Biol Fishes 94:1-6

Reese C, Hillgruber N, Sturdevant M, Wertheimer A, Smoker W, Focht R (2008) Spatial and temporal distribution and the potential for estuarine interactions between wild and hatchery chum salmon (Oncorhynchus keta) in Taku Inlet, Alaska. Fish Bull 107:433-450

Reisenbichler RR, Rubin SP (1999) Genetic changes from artificial propagation of Pacific salmon affect the productivity and viability of supplemented populations. ICES J Mar Sci 56:459-466

* Ruggerone GT, Peterman RM, Dorner B, Myers KW, Mantua NJ (2010) Abundance of adult hatchery and wild salmon by region of the North Pacific. SAFS-UW-1001, School of Aquatic and Fisheries Sciences, University of Washington, Seattle, WA. https://digital.lib.washington. edu/researchworks/bitstream/handle/1773/16262/1001r. pdf; sequence $=1$ (accessed July 2010)

* Scheer BT (1939) The homing instinct in salmon. Q Rev Biol 14:408-430

Schroder SL (1982) The influence of intersexual competition on the distribution of chum salmon in an experimental stream. In: Brannon EL, Salo EO (eds) Proceedings of the Salmon and Trout Migratory Behavior Symposium. University of Washington Press, Seattle, WA, p 275-285

Schtickzelle N, Quinn TP (2007) A metapopulation perspective for salmon and other anadromous fish. Fish Fish 8: 297-314

Seber GAF (1982) The estimation of animal abundance and related parameters, $2^{\text {nd }}$ edn. Blackburn Press, Caldwell, NJ

* Sergeant CJ, Bellmore JR, McConnell C, Moore JM (2017) High salmon density and low discharge create periodic hypoxia in coastal rivers. Ecosphere 8:e01846

Skannes P, Hagerman G, Shaul L (2016) Annual management report for the 2015 Southeast Alaska/Yakutat salmon troll fisheries. Fishery Management Report No. 16-05, Alaska Department of Fish and Game, Anchorage, AK

Steen RP, Quinn TP (1999) Egg burial depth by sockeye salmon (Oncorhynchus nerka): implications for survival of embryos and natural selection on female body size. Can J Zool 77:836-841

Stopha M (2014) An evaluation of the Macaulay salmon hatchery for consistency with statewide policies and prescribed management practices. Regional Information Report 5J14-03, Alaska Department of Fish and Game, Division of Commercial Fisheries, Anchorage, AK

Stopha M (2016) Alaska salmon fisheries enhancement program 2015 annual report. Regional Information Report 5J16-03, Alaska Department of Fish and Game, Division of Commercial Fisheries, Anchorage, AK

* Sturdevant MV, Fergusson E, Hillgruber N, Reese C and others (2012) Lack of trophic competition among wild and hatchery juvenile chum salmon during early marine residence in Taku Inlet, Southeast Alaska. Environ Biol Fishes 94:101-116

* Taylor EB (1991) A review of local adaptation in Salmo- 
nidae, with particular reference to Pacific and Atlantic salmon. Aquaculture 98:185-207

Tillotson MD, Quinn TP (2016) Beyond correlation in the detection of climate change impacts: testing a mechanistic hypothesis for climatic influence on sockeye salmon (Oncorhynchus nerka) productivity. PLOS ONE 11: e0154356

van den Berghe EP, Gross MR (1984) Female size and nest depth in coho salmon (Oncorhynchus kisutch). Can J Fish Aquat Sci 41:204-206

Vercessi L (2012) Alaska salmon fisheries enhancement program 2011 annual report. Fishery Management Report No. 12-04, Alaska Department of Fish and Game, Anchorage, AK

Vercessi L (2013) Alaska salmon fisheries enhancement program 2012 annual report. Fishery Management Report No. 13-04, Alaska Department of Fish and Game, Anchorage, AK

Vercessi L (2014) Alaska salmon fisheries enhancement program 2013 annual report. Fishery Management Report No. 14-12, Alaska Department of Fish and Game, Anchorage, AK

Vercessi L (2015) Alaska salmon fisheries enhancement program 2014 annual report. Fishery Management Report No. 15-15, Alaska Department of Fish and Game, Anchorage, AK

Volk EC, Schroder SL, Grimm JJ (1999) Otolith thermal marking. Fish Res 43:205-219

Vollestad LA, Peterson J, Quinn TP (2004) Effects of fresh-

Editorial responsibility: Ian Fleming,

St. John's, Newfoundland and Labrador, Canada water and marine growth rates on early maturity in male coho and Chinook salmon. Trans Am Fish Soc 133: 495-503

Walters CJ, Juanes F (1993) Recruitment limitation as a consequence of natural selection for use of restricted feeding habits and predation risk taking by juvenile fishes. Can J Fish Aquat Sci 50:2058-2070

Waples RS (1991) Genetic interactions between hatchery and wild salmonids: lessons from the Pacific Northwest. Can J Fish Aquat Sci 48:124-133

Waples RS (1999) Dispelling some myths about hatcheries. Fisheries (Bethesda, Md) 24:12-21

White B (2011) Alaska salmon fisheries enhancement program 2010 annual report. Fishery Management Report No. 11-04, Alaska Department of Fish and Game, Anchorage, AK

* Williamson KS, Murdoch AR, Pearsons TN, Ward EJ, Ford MJ (2010) Factors influencing the relative fitness of hatchery and wild spring Chinook salmon (Oncorhynchus tshawyscha) in the Wenatchee River, Washington, USA. Can J Fish Aquat Sci 67:1840-1851

Yamamoto T, Reinhardt UG (2003) Dominance and predator avoidance in domesticated and wild masu salmon Oncorhynchus masou. Fish Sci 69:88-94

*aporozhets OM, Zaporozhets GV (2012) Some consequences of Pacific salmon hatchery production in Kamchatka: changes in age structure and contributions to natural spawning populations. Environ Biol Fishes 94: 219-230

Submitted: July 31, 2017; Accepted: January 26, 2018 Proofs received from author(s): March 8, 2018 